BENM 2021

International Scientific and Practical Conference "Biotechnology, Ecology, Nature Management"

\title{
ALGORITHMS FOR PREVENTIVE MEASURES FOR DISEASE PREVENTION AND ANTIOXIDANT PROTECTION
}

\author{
V. A. Purtskhvanidze (a)*, O. A. Orlovtseva (b), S. N. Tefikova (c), M. V. Klokonos (d) \\ *Corresponding author
}

(a) Medical Center of High Technologies "LaserVita", Moscow, Russia, violetta@laservita.ru

(b) K.G. Razumovsky Moscow State University of Technologies and Management (the First Cossack University), Moscow, Russia

(c) K.G. Razumovsky Moscow State University of Technologies and Management (the First Cossack University), Moscow, Russia

(d) K.G. Razumovsky Moscow State University of Technologies and Management (the First Cossack University), Moscow, Russia

\begin{abstract}
The worsening, every year, the ecological situation in the world leads to the effect of various toxicants on a person, the formation of free radicals in his body and the development of diseases, including cancer. With their high chemical activity, free radicals form oxidative stress, which leads to intoxication, damage and cell death. One of the main tools in removing toxins from the body is not only enzymes of the cytochrome P450 family, but also the human antioxidant system. Various gene polymorphisms responsible for protecting the body from toxins can lead not only to a decrease in the production of enzymes that carry out the oxidative biotransformation of toxins, but also to a decrease in the protective function of antioxidant system. For 30 patients suffering from chronic and dangerous diseases, molecular genetic studies were carried out and gene polymorphisms responsible for antioxidant system. The genetic characteristics of the antioxidant status described in the article, a prophylactic doctor should recommend a detoxification program, individual nutrition, taking into account the necessary nutritional supplements.
\end{abstract}

2672-8575 ㄷ 2022 Published by European Publisher.

Keywords: Antioxidants, free radicals, genetic information, oxidative stress, polymorphism 


\section{Introduction}

Today genetics is a progressive science, and its role will increase every year, as it provides an understanding of the important aspects of human biology and physiology. Thanks to molecular genetic research, the causes of diseases are identified, highly effective drugs are being developed, methods of treating hereditary and intractable diseases. In modern medicine, thanks to the development of genetics, the generally accepted paradigms should shift towards the development of a preventive direction and the creation of algorithms for maintaining human homeostasis, healing it, prolonging youth and managing one's own health. The human genome contains information of two types - genetic and epigenetic. Genetic information is that information that is responsible for the creation of an organism, and it remains unchanged. Epigenetics investigates changes in the expression of certain DNA sequences that cannot be explained by the classic mutations and structural abnormalities that lead to the development of most diseases. Based on this, epigenetics can be considered as a higher level of genetic organization and regulation.

In connection with the deterioration of the ecological situation, the scientific interest in the effect of free radicals on the expression of genes that lead to the development of diseases has been increasing recently. Free radicals formed in human tissues are highly reactive. Normally, they take part in the biochemical and physiological processes of the human body. To prevent the "overload" of free radicals and peroxides, the body uses complex enzymatic and non-enzymatic systems of the body's defense. In a number of pathophysiological conditions, the balance between free radicals and antioxidant defense can be changed, oxidative stress develops, and cell damage and death occurs.

It is known that the development of a number of pathological conditions of the human body, such as cardiovascular pathologies, stroke, Alzheimer's disease, Parkenson's disease, diabetes mellitus, allergic and dermatological diseases, precancerous, oncological and many other diseases are accompanied by an increase in the formation of activated oxygen metabolites and free radicals (Berezina et al., 2019; Ivanova et al., 2019; Karpov et al., 2019; Nikitina et al., 2018).

Free radicals (oxidants, oxidants) are molecules that lack one or more electrons on the outer electron shell, therefore their molecules have a high chemical activity, taking away electrons from other molecules, oxidizing any compounds with which they come in contact and cause "oxidative stress ".

Sources of free radicals can be both external and internal factors. External factors include: environmental pollution, soil acidification, preservatives, antibiotics, xenobiotics, drugs, computers, televisions, mobile phones, cigarette smoke, radiation, smoking, highly oxidizing drinks, sunlight, chlorinated water, and more.

Internal factors are those factors that occur in the human body: in the processes of energy generation in mitochondria, in the process of the breakdown of harmful fats in the body, in the burning of poly-saturated fatty acids, in inflammatory processes, metabolic disorders, etc.

Psycho-emotional stress also contributes to oxidative stress. Stress causes the body to produce excess amounts of adrenaline and cortisol. In large quantities, these hormones disrupt the normal course of metabolic processes and contribute to the appearance of free radicals throughout the body. 
The human antioxidant system (AOS) is a system that blocks the formation of highly active free radicals. Enzymes synthesized by eukaryotic and prokaryotic cells are antioxidants of enzymatic nature. Antioxidants are enzymatic and non-enzymatic. The most famous antioxidant enzymes (AOF) are catalytic proteins: superoxide dismutase, catalase and peroxidase. Thanks to AOF, each cell is normally capable of destroying excess free radicals, however, with an excess of non-neutralized free radicals, the external part of the antioxidant system - antioxidants obtained from food - plays a significant role in protecting the body from oxidative stress.

Non-enzymatic antioxidants include: ascorbic acid (vitamin C), tocopherol (vitamin E), Vitamin D, Vitamin K, vitamins B2, B5, B6, $\beta$-carotene (provitamin A), lycopene, polyphenols (flavin and flavanoids), tannins, anthocyanins, omega- 3 and omega- 6 polyunsaturated fatty acids, as well as trace elements ( $\mathrm{Fe}, \mathrm{Cu}, \mathrm{Zn}, \mathrm{Se}, \mathrm{S}, \mathrm{Co}, \mathrm{Mn}, \mathrm{Mg}$ ).

\section{Purpose of the Study}

To estimate the contribution of polymorphic variants rs4880 (MNSOD gene), rs947894 (GSTP1 gene), rs4654748 (ALPL gene), rs1801133 (MTYFR gene), rs602662 (FUT2 gene), rs964184 (APOA5 gene), rs12934122 (BCsMO44), responsible for the antioxidant status of a person, in a decrease in cellular immunity and the development of intractable diseases.

\section{Research Methods}

Today, to assess the antioxidant status of a person and optimize therapy, patients are offered the following study: "Comprehensive assessment of oxidative stress", which assesses the presence of antioxidant enzymes, including: albumin, transferrin, uric acid, lipoic acid, glutathione, ubiquinone, oxidized form, vitamins $\mathrm{E}$ and $\mathrm{C}$, A, etc., microelements and human immune status. In $70 \%$ of cases, already at the initial stages of the development of the disease, the indicators of oxidative stress in the blood serum remain normal, and in most cases the trace elements remain unchanged or slightly reduced. To organize preventive measures aimed at creating personalized nutrition, justified introduction of dietary supplements into the diet, adjusting lifestyle, patients should be recommended molecular genetic studies.

We examined and analyzed 30 patients aged 20 to 76 years with allergic, precancerous and oncological diseases. All patients were verified. Patients with allergic diseases, such as photodermatosis and eczematous dermatitis, were examined for the presence of immunoglobulin E, eosinophilic cationic protein, a complete blood count with a leukocyte formula, an extended biochemical analysis of blood, trace elements, and antioxidant status in the blood serum was also determined in all patients. Patients with precancerous and oncological diseases, such as leukoplakia of the oral mucosa and vulva, Keir's disease and cervical cancer, underwent cytological examination and analysis for human papillomavirus (HPV).

All patients underwent a molecular genetic study and a personal genetic report was drawn up. Material for molecular genetic studies was taken with a special cotton swab from the buccal epithelium of the buccal mucosa and placed in a special container. The container, together with the patient's questionnaire, which indicated: gender, age, height, body mass index, physical activity coefficient, were sent to the Molecular Genetics Laboratory "Mu Genetics". DNA report "Exert" - a detailed DNA test for 
the prevention of metabolic disorders, as well as the preparation of individual programs to reduce the risk of diseases and improve overall health. The professional DNA report is based on the latest scientific research on the association of genes with human diseases and traits. All scientific studies are based on evidence-based clinical efficacy.

The report examined the following polymorphisms: rs4646994 (ACE gene), rs1815739 (ACTN3 gene), rs4961 (ADD1 gene), rs1229984 (ADH1B gene), rs1034714 (ADRB2 gene), rs4994 (ADRB3 gene), rs465448 (APOA5 gene), rs429358, rs7412 (APOE gene) rs1761667 (CD36 gene), rs12934922 (BCMO1 gene), rs5882 (CETP gene), rs1051730 (CHRNA5 gene), rs1799998 (CYP11B2 gene) (gene CYP11B2) (rs761800 DRD2 gene), rs1799883 (FABP2 gene), rs174547 (FADS1 gene), rs9939609 (FTO gene), rs602662 (FUT2 gene), rs5400 (GLUT2 gene), rs947894 (GSTP1 gene), rs2395182 (HLADQ22 gene) ), rs17782313 (MC4R gene), rs4880 (MNSOD gene), rs1801133 (MTHFR gene), rs1805192 (PPARG gene), rs1726866 (TAS2R38 gene), rs12255372 (TCF7L2 gene), rs1544410 (VDR gene).

The ACE gene encodes angiotensin-converting enzyme (ACE), a protein circulating in the extracellular space that plays an important role in the regulation of blood pressure and electrolyte balance, catalyzes the breakdown of inactive angiotensin I to active angiotensin II, which stimulates vasoconstriction and increases aldosterone synthesis. It is associated with the type of adaptation of the cardiovascular system to a certain type of physical activity and the development of hypertrophic cardiomyopathy and arterial hypertension. Deletion (D) in this gene is associated with adaptation of the cardiovascular system to stress loads and, at the same time, with an increased risk of arterial hypertension (He et al. 2013). This gene is responsible for the water-salt balance in the body and the elimination of water from the body (Armanini et al., 2018).

The ACTN3 gene encodes the alpha-actinin-3 protein, which is involved in the contractile apparatus of skeletal muscle fibers and is expressed mainly in them. A polymorphic substitution in this gene results in the absence of a functional protein, alpha-actinin-3. In this case, its role is played by alphaactinin-2, which is characterized by a low rate of contraction of muscle fibers. ACTN3 is a specific marker for speed and strength. (Eynon et al., 2013; Mikami et al., 2014; Papadimitriou et al. 2016).

The ADD1 gene encodes the cytoskeleton and membrane protein alpha-adducin and is associated with changes in the transport of sodium ions in cells. Investigated to identify a genetic predisposition to salt-sensitive hypertension and a tendency to edema (Da Silva et al., 2019).

The ADH1B gene encodes the beta subunit of alcohol dehydrogenase. It is an enzyme in the first phase of detoxification of xenobiotics and oxidizes ethanol to acetaldehyde. The efficiency of the enzyme determines the sensitivity to alcohol. Polymorphism is associated with the development of alcohol dependence and alcoholic cirrhosis of the liver (Bühler et al., 2015; Ferraguti et al., 2015; Zaridze et al., 2009).

The ADRB2 gene encodes a beta-2-adrenergic receptor, an ionic protein channel built into the cytoplasmic membrane of a cell that has a high affinity for adrenaline and provides an increase or decrease in the metabolic activity of an innervated tissue or organ (Snyder et al., 2006). Activation of receptors causes an increase in the intensity of glycogenolysis (the breakdown of glycogen to glucose) in the muscles. There are two loci in the gene: Gln27Glu (associated with obesity and glycogenolysis, breakdown of glycogen during physical activity) and Gly16Arg (associated with cardiac output at rest, 
increased bronchodilation (relaxation of the muscle layer in the bronchi) and endurance) (Blanchet et al., 2018; Chughtai et al., 2017; Ginevičienè et al., 2011).

The ADRB3 gene encodes beta-3-adrenergic receptors. ADRB3 is located primarily in adipocytes (adipose tissue cells). Agonists of this receptor subtype stimulate lipolysis (lipolysis) and thermogenesis (heat production). Polymorphism in this gene is associated with a slowdown in the lipolysis process. Carriers of this gene variant need more intense exercise to lose weight (Celis-Morales et al., 2016; Leońska-Duniec et al., 2018).

The ALPL gene encodes alkaline phosphatase, the main enzyme involved in the inactivation of the biologically active form of vitamin B6. Some variants of this gene are associated with a decrease in the concentration of this vitamin, in such cases it is recommended to increase its intake (Albersen, 2013; Carter et al., 2015; Kim \& Cho, 2014).

The APOA5 gene encodes apolipoprotein 5, a minor plasma apolipoprotein. In plasma, it is mainly associated with triglyceride levels and to a lesser extent with low and very low density lipoproteins. Plays an important role in determining the concentration of triglycerides in the blood, as it stimulates lipolysis (cleavage) of triglycerides by lipoprotein lipase. One of the functions of this protein is the transport of fatsoluble vitamin E. Polymorphic substitution in this gene is associated with an increase in triglyceride and LDL levels (Spracklen et al., 2017).

The APOE gene encodes the formation of a lipoprotein carrier protein. Apolipoprotein is a component of chylomicrons and very low density lipoproteins. Its functions are to ensure the metabolism of lipids in the blood and cholesterol in the brain. Polymorphisms are associated with the risks of atherosclerosis and / or Alzheimer's disease (Rodríguez et al., 2006; Spracklen et al., 2017).

The BCMO1 gene encodes the beta-carotene monooxygenase enzyme, which in the human body is involved in the conversion of carotenoids into retinol, the active form of vitamin A. Nucleotide substitution in the gene leads to a decrease in the enzyme activity and impairment of the digestibility of provitamin A and carotenoids (Hendrickson et al., 2012; Leung et al., 2009; Lindqvist et al., 2007).

The CD36 gene encodes a fatty receptor, which is an integral membrane protein responsible for the metabolism of fatty acids, recognition of fats in food, taste, and digestion of fats in the intestine. Polymorphism in this gene is associated with the taste perception of the texture of fatty foods and excess fat intake (Lu et al., 2016).

The CETP gene encodes a cholesterol ester transporter protein involved in the transfer of cholesterol esters from HDL to LDL. Polymorphism is associated with an increased risk of developing disorders of fat and carbohydrate metabolism, which can lead to hypercholesterolemia (increased cholesterol concentration), metabolic syndrome, and the development of coronary heart disease (Weingaertner et al., 2011; Willer et al., 2013).

The CHRNA5 gene encodes one of the structures of the alpha-5-nicotinic cholinergic receptor, through which the action of the neurotransmitter acetylcholine, which plays an important role in the processes of memory and learning, is realized. When smoking, the receptor binds to nicotine, which makes it difficult to transmit a nerve impulse. Polymorphism is associated with the development of nicotine addiction and predisposes to lung disease (Ducci et al., 2011; Weiss et al., 2008; Wood et al., 2009). 
The CYP11B2 gene encodes the enzyme aldosterone synthase, which is one of the components of the renin-angiotensin system, which regulates blood pressure and the volume of pumped blood in the body. The enzyme catalyzes the last step in the synthesis of the hormone aldosterone from deoxycorticosterone. Aldosterone, in turn, plays a role in the regulation of blood pressure by maintaining water-salt balance, is activated by potassium and promotes its excretion according to the principle of feedback (Gomes-Sanches et al., 2017; Jia et al., 2013; MdDonough et al., 2017).

The CYP1A2 gene encodes an enzyme in the first phase of detoxification, cytochrome 1A2, which is involved in the metabolism of many substances, including drugs, steroids, and caffeine. Polymorphism in this gene is associated with a deterioration of the enzyme and, as a consequence, a slowdown in the conversion of caffeine, which contributes to the development of arterial hypertension (Gubitosa et al., 2019; Tian et al., 2013; Wiegand et al., 2014).

The DRD2 gene encodes the dopamine D2 receptor, which is located on the surface of dopaminergic neurons and triggers a cascade of reactions within the cell under the influence of dopamine. It stands out as a reward, when visualizing a desired result, when a goal is achieved, and evokes a sense of pleasure. Polymorphism is associated with the risk of addiction formation (Benton \& Young, 2016; Harrison, 2019; Patriquin et al., 2015).

The FABP2 gene encodes a type 2 fatty acid transporter. Protein binds fatty acids in the small intestine, promotes their more active assimilation, has a high affinity for saturated fats, provides uptake, intracellular transport and metabolism of long-chain fatty acids. Polymorphism in this gene is associated with the accelerated transport of saturated fatty acids (Tae-Kyung Han, 2019).

The FADS1 gene encodes fatty acid desaturase, an enzyme that converts monounsaturated fatty acids into polyunsaturated fatty acids. The enzyme converts omega-3 to eicosapentaenoic acid and omega-6 to arachidonic acid. Polymorphism in the gene is associated with a decrease in the formation of PUFA from plant sources (Shramko, 2020).

The FTO gene encodes 2-oxoglutarate-dependent demethylase, which is involved in the modification of nucleic acids that perform a regulatory function. The enzyme is produced in the nervous tissue and activates the release of the hunger hormone ghrelin. The gene polymorphism is associated with an increased feeling of hunger after meals (De Luis et al., 2015; Merrit et al., 2018; Zhang et al., 2012).

The FUT2 gene encodes the production of a component of a special factor that is necessary for the absorption of vitamin B12 in the gastrointestinal tract, which also plays a role in the pathogenesis of Crohn's disease. Polymorphism in this gene is associated with impaired absorption of vitamin B12 (Ertug et al., 2018; Tanwar et al., 2013; Wolffenbuttel et al., 2019).

The GLUT2 gene encodes a glucose transporter protein that transports glucose across the cell membrane through facilitated diffusion. Polymorphism in this gene is associated with a decrease in the rate of glucose transport and excess sugar consumption (Cornelis et al., 2009; Corella et al., 2013; Kellett et al., 2008).

The GSTP1 gene encodes an enzyme of the second phase of detoxification, which binds glutathione to xenobiotics: drugs, toxins, products of oxidative stress, etc. Participates in the deactivation of many compounds, in particular those formed during heat treatment. Polymorphism reduces the 
efficiency of detoxification of substances that enter the body with fried food (Carlsen et al., 2010; Costa et al., 2012; Landete, 2013).

The HLA gene encodes a subunit of the major histocompatibility complex II, another name for which is human leukocyte antigen. The genes of this system are responsible for recognizing their own cells. Antigen-presenting cells carrying HLADQ22 in combination with deaminated gliadin peptides present antigens to $\mathrm{T}$ cells, which leads to the triggering of chronic inflammation in the mucous membrane of the small intestine and the development of celiac disease. Certain variants of this gene are associated with high sensitivity to gluten (Dubois et al., 2010; Fallang et al., 2009; Lund et al., 2015).

The studied polymorphism is located not directly in the LCT gene, but in the MCM6 gene encoding the replicative factor of the MCM group, which is necessary for the stage of genome replication initiation (synthesis of the daughter DNA molecule). In turn, MCM6 has 2 regulatory regions of the LCT gene, which encodes the enzyme lactase. Lactase is produced in the small intestine and is involved in the breakdown of milk sugar - lactose. Normally, lactase activity decreases with age, but the MCM6 (LCT) polymorphism is associated with the retention of its activity and the ability to assimilate milk in adulthood (Alliende et al., 2016; Almon et al., 2013, Tomczonek-Moruś et al., 2019).

The MC4R gene encodes type 4 melanocortin receptor, which mediates the regulation of eating behavior and maintenance of body weight. Produced in the central nervous system. Through this receptor, a signal is triggered to suppress hunger and reduce food intake. Polymorphism is associated with eating disorders (Adamska-Patruno et al., 2019).

The MNSOD gene encodes a mitochondrial enzyme involved in the detoxification of reactive oxygen species, converting them into a less aggressive form, which is further transformed by other enzymes. Polymorphism in this gene is associated with an increase in the level of oxidative stress due to worsening inactivation of oxygen radicals, which leads to damage to cellular structures (Carlsen et al., 2010; Costa et al., 2012; Landete, 2013).

The MTHFR gene is a folate cycle gene that encodes methylenetetrahydrofolate reductase, an intracellular enzyme involved in the conversion of homocysteine to methionine in the presence of vitamins B6, B12 and folic acid. Investigated to identify a genetic predisposition to the development of hyperhomocysteinemia (increased levels of homocysteine in the blood) and atherosclerosis. Polymorphism in this gene is associated with an increased demand for folic acid (Ievleva, 2016).

The PPARG gene encodes a gamma-nuclear receptor that regulates the expression of genes involved in cell differentiation, muscle tissue metabolism, and the metabolism of fats and carbohydrates. Polymorphism in the gene is associated with a change in the growth process of adipose tissue (Kamble et al., 2018; Hsiao \& Lin, 2015; Matsuo et al., 2009).

The TAS2R38 gene encodes a protein on the membrane of tongue cells that respond to bitter taste. First of all, it determines the sensitivity to phenylcarbamide. Various natural compounds also have a bitter taste: tannins, catechins, anthocyanins, isoflavones, glucosinolates, bioflavonoids. All of these substances are natural antioxidants. Also, variants of this gene are associated with a preference for certain alcoholic beverages (Deshaware \& Singhal, 2017; Mezzavilla et al., 2019; Nolden et al., 2016).

The TCF7L2 gene encodes a transcription factor that is involved in blood glucose homeostasis (balance, constancy), stimulating the differentiation of insulin-producing pancreatic beta cells, as well as 
through interaction with the proglucagon gene, which determines glucose-induced insulin secretion. Polymorphism in this gene makes a significant contribution to the development of type 2 diabetes (Cornelis et al., 2009; Corella et al., 2013; Kellett et al., 2008).

The VDR gene encodes a vitamin D receptor, it is associated with mineral metabolism, and is also involved in the regulation of hair growth and renewal of the stratum corneum. Polymorphism in this gene is associated with a decrease in the sensitivity of the receptor to vitamin $\mathrm{D}$, which leads to fragility of bones, teeth and hair, and also contributes to the early development of osteoporosis (Pouresmaeili et al., 2013; Wu et al., 2016; Yin et al., 2018).

When analyzing the genetic reports of all patients, insignificant polymorphisms of different genes were noted, but almost all of them had canceled polymorphisms in the genes responsible for AOS (see Table 1).

Table 1. Distribution of patients by diagnosis and study title

\begin{tabular}{|c|c|c|c|c|c|c|c|c|c|c|c|}
\hline Diagnosis & $\mathbf{M}$ & $\mathbf{F}$ & $\begin{array}{l}\text { Molecular } \\
\text { genetic } \\
\text { research }\end{array}$ & $\begin{array}{c}\text { Clinica } \\
\text { blood } \\
\text { test }\end{array}$ & Immunoglobulin & $\begin{array}{l}\text { Iosinophilic } \\
\text { cationic } \\
\text { protein }\end{array}$ & $\begin{array}{l}\text { Cytological } \\
\text { examination }\end{array}$ & $\begin{array}{r}\text { HPV } \\
\text { test }\end{array}$ & $\begin{array}{c}\text { Blood } \\
\text { chemistry }\end{array}$ & $\begin{array}{l}\text { Trace } \\
\text { elements }\end{array}$ & $\begin{array}{l}\text { Comprehensive } \\
\text { assessment of } \\
\text { oxidative stress }\end{array}$ \\
\hline $\begin{array}{l}\text { Leukoplakia of } \\
\text { the vulva }\end{array}$ & & 6 & + & + & + & + & + & + & + & + & + \\
\hline $\begin{array}{c}\text { Leukoplakia of } \\
\text { the tongue }\end{array}$ & 3 & 4 & + & + & + & + & + & + & + & + & + \\
\hline $\begin{array}{l}\text { Eczematous } \\
\text { dermatitis }\end{array}$ & 5 & 3 & + & + & + & + & & & + & + & + \\
\hline Photodermatosis & s 2 & 2 & + & + & + & + & & & + & + & + \\
\hline Cervical cancer & 3 & & + & + & + & + & + & + & + & + & + \\
\hline Disease & & 2 & + & + & + & + & + & + & + & + & + \\
\hline Total & 13 & & & & & & & & & & \\
\hline
\end{tabular}

In 12 patients with allergic and eczematous diseases, in 2 patients, neutrophils were decreased (30\% and $34.9 \%$ ), in 3 patients there was an increase in lymphocytes (50.5\% and $52 \%$ ), in 4 patients - an increase in eosinophils (5.5\% and 5.7\%), 3 had an increase in absolute eosinophils (0.86, 0.93, 0.98 thousand $/ \mu \mathrm{L}$ ), one patient had a decreased hemoglobin - $10.2 \mathrm{~g} / \mathrm{dl}$., two patients showed an increase in $\operatorname{lgE}$ (220 and 420 units / $\mathrm{ml})$, two patients showed an increase in eosinophilic cationic protein $(28 \mathrm{ng} / \mathrm{ml}$ and $36 \mathrm{ng} / \mathrm{ml}$ ). In two patients, an increase in ALT (62 U / L), and in one AST (55 U / L), one patient had a decrease in selenium. The overall antioxidant status in all dermatological patients was normal.

Among patients with precancerous and oncological diseases: two patients had increased eosinophils in the blood serum (6.2\%), one patient had an increased creatinine $(120 \mu \mathrm{mol} / \mathrm{L})$, one patient had low vitamin C. Microelements in all oncological patients were normal.

In the DNA report, polymorphisms of 102 genes were examined. The genetic report is based on data obtained as a result of DNA analysis and on the basis of an assessment of the patient's lifestyle following a questionnaire. The report identifies genetic predispositions to certain physiological conditions, and also indicates the characteristics associated with nutrition and physical activity. Genes determine a person's health by $40 \%, 50 \%$ depend on lifestyle (habits, nutrition, sports, ecological environment) and only $10 \%$ on purposeful health improvement and treatment. 
Table 2. Investigated genes responsible for the antioxidant defense of the body

\begin{tabular}{ccc}
\hline Name & Gene & Polymorphism \\
\hline Antioxidants & MNSOD & rs4880 \\
Detoxification of xenobiotics & GSTP1 & rs947894 \\
Vitamin B6 & ALPL & rs4654748 \\
Vitamin B9 & MTYFR & rs1801133 \\
Vitamin B12 & FUT2 & rs602662 \\
Vitamin E & APOA5 & rs964184 \\
Vitamin A & BCMO1 & rs 12934922 \\
Vitamin D & VDR & rs 1544410 \\
\hline
\end{tabular}

When analyzing 30 genetic reports, the effectiveness of the antioxidant system, the rate of detoxification of the superoxide radical, the rate of excretion of B vitamins, the need for B vitamins, folic acid metabolism, the risk of homocysteinemia, the absorption of vitamin B12 through the gastrointestinal tract, the need for vitamin B12, the need for vitamin E, the tendency to increase the concentration of vitamin $\mathrm{E}$, the absorption of vitamin A from plant acids, the need for vitamin A, sensitivity to vitamin $\mathrm{D}$, the need for vitamin D (see Table 2).

\section{Findings}

Genetic analysis showed that $97 \%$ of patients have expression of the MNSOD gene, which leads to a weakening of the antioxidant defense of the body and a decrease in immunity. In $80 \%$ of cases, there were changes in the GSTP1 gene, which is also associated with impaired immunity. It was also revealed that the expression of the ALPL and VDR genes in $80 \%$ of patients leads to the development of vitamin B6 and D deficiency, impaired protein metabolism, impaired functioning of the nervous system, the development of various dermatoses, as well as a decrease in immunity. Expression of genes MTYFR, FUT2, APOA5, BCMO1 leads to an increased risk of hyperhomocysteinemia associated with the activity of the enzyme methylenetetrahydrofolate reductase, disorders of the cardiovascular system and neurological diseases. The development of vitamin B9 deficiency may also be due to the slow conversion of folic acid to the active form in the form of 5-methylenetetrahydrofolate. Signs of an excess and decrease in vitamin B9 can lead to the development of neoplasms, vitamin B12 vitamin deficiency, mood swings, increased excitability, and deterioration of kidney function. Expression of the FUT2 gene can lead to various allergic reactions, tachycardia, bleeding disorders, and nervous system disorders. The APOA5 gene, which is responsible for signs of excess and deficiency of vitamin E, showed that $90 \%$ of patients have a risk of developing hypertriglyceridemia and an increased need for vitamin E, which can cause anemia, infertility and muscular dystrophy. Expression of the BCMO1 gene leads to impaired absorption of carotenoids and, as a result, dryness, thinning of the skin, and impaired functioning of the immune system.

In the recommendations, patients with changes in the MNSOD and GSTP genes were recommended to be tested for the following substances:

- 8-OH-deoxyguanosimene - in blood and urine,

- malondialdehyde - in the blood. 
If the patient smokes, then reduce the number of cigarettes, be more careful with tanning. To maintain health, it is recommended to exclude or limit sources of intoxication: opisthorchiasis, alcohol, synthetic drugs.

In case of changes in the ALPL gene and for the prevention of hypervitaminosis, patients were recommended to be tested for pyridoxal-5-phosphate. When expressed in the MTYFR gene, it is recommended to control the level of homocysteine in the blood, to be tested for the content of folic acid.

\section{Conclusion}

On the basis of DNA analysis, one can judge the genetic characteristics of an organism. All patients showed a predisposition to a violation of the antioxidant defense of the body and, as a consequence, a decrease in immunity, which could lead to the development of diseases. It is also worth noting that diseases such as vulvar leukoplakia and oropharyngeal leukoplakia, as well as Keir's disease and cervical cancer, are acquired diseases associated with the human papillomavirus. HPV in this case acts as an agent that lowers human immunity. After completion of treatment, these patients need preventive treatment in order to prevent relapse, lifestyle adjustments, sleep and nutrition. Taking into account the genetic characteristics of the antioxidant status, a preventive medicine doctor should recommend a detoxification program, personalized nutrition, taking into account the necessary dietary supplements. Genetic studies will help doctors analyze the patient's condition and prescribe competent preventive therapy.

\section{Acknowledgments}

The work was carried out with the financial support of the Russian Foundation for Basic Research in the framework of grant No. 20-316-90043 «Substantiation of approaches and development of methodology for designing products and diets of personalized nutrition for consumers with a predisposition to violation of bone mineral density and the development of osteoporosis».

\section{References}

Adamska-Patruno, E., Goscik, J., Czajkowski, P., Maliszewska, K., Ciborowski, M., Golonko, A., Natalia Wawrusiewicz-Kurylonek, N., Citko, A., Waszczeniuk, M., Kretowski, A., \& Gorska, M. (2019). The MC4R genetic variants are associated with lower visceral fat accumulation and higher postprandial relative increase in carbohydrate utilization in humans. European journal of nutrition, 58(7), 2929-2941. https://doi.org/10.1007/s00394-019-01955-0

Albersen, M. (2013). The metabolism of vitamin B6 in relation to genetic disease [Doctoral dissertation], Utrecht University.

Alliende, F., Vial, C., Espinoza, K., Schnettle, D., Romero, V., Miquel, I., Arancibia, M. E., Rios, G., Rodriguez, L., Quesada, S., Lucero, Y., \& Repetto, G. M. (2016). Accuracy of a genetic test for the diagnosis of hypolactasia in Chilean children: Comparison with the breath test. Journal of pediatric gastroenterology and nutrition, 63(1), e10-e13. https://doi.org/10.1097/MPG.0000000000001208

Almon, R., Sjoestroem, M., Nilsson \&, T. K. (2013). Lactase non-persistence as a determinant of milk avoidance and calcium intake in children and adolescents. Journal of Nutrition Science, 2, e26. https://doi.org/10.1017/jns.2013.11 
Armanini, D., Bordin, L., Dona', G., Andrisani, A., Ambrosini, G., \& Sabbadin, C. (2018). Relationship between water and salt intake, osmolality, vasopressin, and aldosterone in the regulation of blood pressure. The Journal of Clinical Hypertension, 20(10), 1455-1457. https://doi.org/10.1111/jch.13379

Benton, D., \& Young, H. A. (2016). A meta-analysis of the relationship between brain dopamine receptors and obesity: a matter of changes in behavior rather than food addiction? International journal of obesity, 40(1), S12-S21. https://doi.org/10.1038/ijo.2016.9

Berezina, N. A., Artemov, A. V., Nikitin, I. A., \& Budnik, A. A. (2019). The method of computer-aided design of a bread composition with regard to biomedical requirements. International Journal of Advanced Computer Science and Applications, 10(5), 137-143. https://doi.org/10.14569/IJACSA.2019.0100517

Blanchet, S., Chikhi, S., \& Maltais, D. (2018). The benefits of physical activities on cognitive and mental health in healthy and pathological aging. Geriatr Psychol Neuropsychiatr Vieil, 16(2), 97-205. https://doi.org/10.1684/pnv.2018.0734

Bühler, K. M., Giné, E., Echeverry-Alzate, V., Calleja-Conde, J., Rodriguez de Fonseca, F., \& LópezMoreno, J. A. (2015). Common single nucleotide variants underlying drug addiction: more than a decade of research. Addiction biology, 20(5), 845-871. https://doi.org/10.1111/adb.12204

Carlsen, M., H., Halvorsen, B. L., Holte, K., Bøhn, S.K., Dragland, S., Sampson, L., Willey, C., Senoo, H., Umezono, Y., Sanada, C., Barikmo, I., Berhe, N., Willett, W.C., Phillips, K.M., Jacobs Jr, D. R., \& Blomhoff, R. (2010). The total antioxidant content of more than 3100 foods, beverages, spices, herbs and supplements used worldwide. Nutrition Journal, 9(3). https://doi.org/10.1186/1475-2891-9-3

Carter, T. C., Pangilinan, F., Molloy, A. M., Fan, R., Wang, Y., Shane, B., Gibney, E. R., Midttun, Ø., Ueland, P. M., Cropp, C. D., Kim, Y., Wilson, A. F., Bailey-Wilson, J. E., Brody, L. C., \& Mills J. L. (2015). Common variants at putative regulatory sites of the tissue nonspecific alkaline phosphatase gene influence circulating pyridoxal 5'-phosphate concentration in healthy adults. The Journal of Nutrition, 145, 1386-1393. https://doi.org/10.3945/jn.114.208769

Celis-Morales C., Marsaux, C. F., Livingstone, K. M., Navas-Carretero, S., San-Cristobal, R., O'donovan, C. B., Forster, H., Woolhead, C., Fallaize, R., Macready, A. L., Kolossa, S., Hallmann, J., Tsirigoti, L., Lambrinou, C. P., Moschonis, G., Godlewska, M., Surwiłło, A., Grimaldi, K., Bouwman, J., ... Mathers, J. C. (2016). Physical activity attenuates the effect of the FTO genotype on obesity traits in European adults: The Food4Me study. Obesity, 24(4), 962-969.

Chughtai, M., Gwam, C. U., Mohamed, N., Khlopas, A., Sodhi, N., Sultan, A. A., Bhave, A., Mont, M. A. (2017). Impact of Physical Activity and Body Mass Index in Cardiovascular and Musculoskeletal Health: A Review. Surgical Technology Institute, 31, 213-220. https://doi.org/10.1002/oby.21422

Corella, D., Carrasco, P., Sorlí, J. V., Estruch, R., Rico-Sanz, J., Martínez-González, M. Á., SalasSalvadó, J., Covas, M.I., Coltell, O., Arós, F., Lapetra, J., Serra-Majem, L., Ruiz-Gutiérrez, V., Warnberg, J., Fiol, M., Pintó, X., Ortega-Azorín, C., Muñoz, M. Á., Martínez, J. A., ... Ordovás, J. M. (2013) Mediterranean diet reduces the adverse effect of the TCF7L2-rs7903146 polymorphism on cardiovascular risk factors and stroke incidence: a randomized controlled trial in a high-cardiovascular-risk population. Diabetes care. https://doi.org/10.2337/dc13-0955

Cornelis, M. C. Qi, L., Kraft, P., \& Hu, F. B. (2009). TCF7L2, dietary carbohydrate, and risk of type 2 diabetes in US women. The American journal of clinical nutrition, 89(4), 1256-1262. https://doi.org/10.3945/ajen.2008.27058

Costa, L. A. D., García-Bailo, B., Badawi, A., \& El-Sohemy, A. (2012) Genetic determinants of dietary antioxidant status. Progress in Molecular Biology and Translational Science, 108, 179-200. https://doi.org/10.1016/B978-0-12-398397-8.00008-3

Da Silva, P. A., Matos, A., Aguiar, L., Ramos-Marques, N., Ribeiro, R., Gil, A., Gorjão-Clara, J., \& Bicho, M. (2019). Hypertension and longevity: role of genetic polymorphisms in reninangiotensin-aldosterone system and endothelial nitric oxide synthase. Mol Cell Biochem, 455, 1-2, 61-71. https://doi.org/10.1007/s11010-018-3470-1 
De Luis, D., Aller, R., Izaola, O., Primo, D., Urdiales, S., \& Romero, E. (2015). Effects of a HighProtein/Low-Carbohydrate Diet versus a Standard Hypocaloric Diet on Weight and Cardiovascular Risk Factors: Role of a Genetic Variation in the rs9939609 FTO Gene Variant. J Nutrigenet Nutrigenomics, 8(3), 128-136. https://doi.org/10.1159/000441142

Deshaware, S., \& Singhal, R. (2017). Genetic variation in bitter taste receptor gene TAS2R38, PROP taster status and their association with body mass index and food preferences in Indian population. Gene, 627, 363-368. https://doi.org/10.1016/j.gene.2017.06.047

Dubois, P. C., Trynka, G., Franke, L., Hunt, K.A., Romanos, J., Curtotti, A., Zhernakova, A., Heap, G. A., Adány, R., Aromaa, A., Bardella, M. T., Van den Berg, L. H., Bockett, N. A., De la Concha, E. G., Dema, B., Fehrmann, R. S., Fernández-Arquero, M., Fiatal, S., Grandone, E., ... Van Heel, D. A. (2010). Multiple common variants for celiac disease influencing immune gene expression. Nature genetics, 42(4), 295-302. https://doi.org/10.1038/ng.543

Ducci, F., Kaakinen, M., Pouta, A., Hartikainen, A. L., Veijola, J., Isohanni, M., Charoen, P., Coin, L., Hoggart, C., Ekelund, J., Peltonen, L., Freimer, N., Elliott, P., Schumann, G., \& Järvelin, M. R. (2011). TTC12-ANKK1-DRD2 and CHRNA5-CHRNA3-CHRNB4 influence different pathways leading to smoking behavior from adolescence to mid-adulthood. Biological psychiatry, 69(7), 650-660. https://doi.org/10.1016/j.biopsych.2010.09.055

Ertug, E., Y., \& Yilmaz, R. (2018). A. Reduced ferritin, folate, and vitamin B12 levels in female patients diagnosed with telogen effluvium. International Journal of Medical Biochemistry, 1(3), 111-114.

Eynon, N., Hanson, E. D., Lucia, A., Houweling, P. J., Garton, F., North, K. N., \& Bishop, D. J. (2013). Genes for elite power and sprint performance: ACTN3 leads the way. Sports medicine, 43(9), 803817. https://doi.org/10.1007/s40279-013-0059-4

Fallang, L. E., Bergseng, E., Hotta, K., Berg-Larsen, A., Kim, C. Y., \& Sollid, L. M. (2009). Differences in the risk of celiac disease associated with HLA-DQ2. Five or HLA-DQ2. Two are related to sustained gluten antigen presentation. Nature immunology, 10(10), 1096-1101. https://doi.org/10.1038/ni.1780

Ferraguti G., Pascale E., \& Lucarelli M. (2015). Alcohol addiction: a molecular biology perspective. $\begin{array}{llll}\text { Current medicinal } & \text { chemistry, }\end{array}$ https://doi.org/10.2174/0929867321666141229103158

Ginevičienė, V., Pranculis, A., Jakaitienè, A., Milašius, K., \& Kučinskas, V. (2011). Genetic Variation of the Human ACE and ACTN3 Genes and Their Association With Functional Muscle Properties in Lithuanian Elite Athletes. Medicina (Kaunas), 47(5), 284-290. https://doi.org/10.3390/medicina47050040

Gomes-Sanches, C. E., Kuppusamy, M., Reincke, M., \& Williams, T. A. (2017). Disordered CYP11B2 Expression in Primary Aldosteronism. Horm Metab Res, 49(12), 957-962. https://doi.org/10.1055/s-0043-122238

Gubitosa, J., Rizzi, V., Fini, P., \& Cosma, P. (2019). Hair care cosmetics: from traditional shampoo to solid clay and herbal shampoo, a review. Cosmetics, 6(1), 13. https://doi.org/10.3390/cosmetics6010013

Harrison, K. (2019). The social potential of music for addiction recovery. Music \& Science, 2, 1-16. https://doi.org/10.1177/2059204319842058

He, Q., Fan, C., Yu, M., Wallar, G., Zhang, Z. F., Wang, L., Zhang, X., \& Hu, R. (2013). Associations of ACE Gene Insertion/Deletion Polymorphism, ACE Activity, and ACE mRNA Expression with Hypertension in a Chinese Population. PLoS One, 8(10), e75870. https://doi.org/10.1371/journal.pone.0075870

Hendrickson, S. J., Hazra, A., Chen, C., Eliassen, A. H., Kraft, P., Rosner, B. A., \& Willett, W. C. (2012). Beta-carotene 15,15'-monooxygenase 1 single nucleotide polymorphisms in relation to plasma carotenoid and retinol concentrations in women of European descent. The American Journal of Clinical Nutrition, 96(6), 1379-1389. https://doi.org/10.3945/ajcn.112.034934

Hsiao, T. J., \& Lin, E. (2015). The Pro12Ala polymorphism in the peroxisome proliferator-activated receptor gamma (PPARG) gene in relation to obesity and metabolic phenotypes in a Taiwanese population. Endocrine, 48(3), 786-793. https://doi.org/10.1007/s12020-014-0407-7 
Ievleva, K. D. (2016). MTHFR folate cycle gene and nutrition. Genetics and proteomics. Bulletin of the VSSC SB RAMS, 1, 3(109), part II, 138-143. https://doi.org/10.12737/article_590823a5316dd5.54345742

Ivanova, V. N., Nikitin, I. A., Zhuchenko, N. A., Nikitina, M. A., Sidorenko, Y. I., Karpov, V. I., \& Zavalishin, I. V. (2019). Clustering of Multidimensional Objects in the Formation of Personalized Diets. International Journal of Advanced Computer Science and Applications, 10. https://doi.org/10.14569/IJACSA.2019.0100206

Jia, M., Zhang, H., Song, X., Pang, X., Ye, W., Miao, W., \& Gu, W. (2013). Association of CYP11B2 polymorphisms with susceptibility to primary aldosteronism: a meta-analysis. Endokr J, 60(7), 861-870. https://doi.org/10.1507/endocrj.EJ12-0455

Kamble P. G., Pereira, M. J., Gustafsson, S., Lundkvist, P., Castillejo-López, C., Fall, T., Ingelsson, E., \& Eriksson, J. W. (2018). Role of peroxisome proliferator-activated receptor gamma Pro12Ala polymorphism in human adipose tissue: assessment of adipogenesis and adipocyte glucose and lipid turnover. Adipocyte, 7(4), 285-296. https://doi.org/10.1080/21623945.2018.1503030

Karpov, V. I., Portnov, N. M., Nikitin, I. A., Sidorenko, Yu. I., Zavalishin, I. V., Petrov, S. M., Podgornova, N. M., Sidorenko, M. Y., \& Shterman, S. V. (2019). Automated Methodology for Optimizing Menus in Personalized Nutrition. International Journal of Advanced Computer Science and Applications, 10(11), 317-322. https://doi.org/10.14569/IJACSA.2019.0101144

Kellett G. L., Brot-Laroche E., Mace, O. J., \& Leturque, A. (2008). Sugar absorption in the intestine: the role of GLUT2. Annu. Rev. Nutr, 28, 35-54. https://doi.org/10.1146/annurev.nutr.28.061807.155518

Kim, Y. N., \& Cho, Y. O. (2014) Evaluation of vitamin B6 intake and status of 20- to 64-year-old Koreans. Nutrition Research and Practice, 8(6), 688-694. https://doi.org/10.4162/nrp.2014.8.6.688

Landete, J. M. (2013). Dietary intake of natural antioxidants: vitamins and polyphenols. Critical Reviews in Food Science and Nutrition, 53(7), 706-721. https://doi.org/10.1080/10408398.2011.555018

Leońska-Duniec, A., Jastrzębski, Z., Jażdżewska, A., Moska, W., Lulińska-Kuklik, E., Sawczuk, M., Gubaydullina, S. I., Shakirova, A. T., Cięszczyk, P., Maszczyk, A., \& Ahmetov, I. I. (2018). Individual Responsiveness to Exercise-Induced Fat Loss and Improvement of Metabolic Profile in Young Women is Associated with Polymorphisms of Adrenergic Receptor Genes. J Sports Sci Med, 17(1), 134-144.

Leung, W. C., Hessel, S., Méplan, C., Flint, J., Oberhauser, V., Tourniaire, F., Hesketh, J. E., von Lintig, J., \& Lietz, G. (2009). Two common single nucleotide polymorphisms in the gene encoding $\beta$ carotene $15,15^{\prime}$-monoxygenase alter $\beta$-carotene metabolism in female volunteers. The FASEB Journal, 23(4), 1041-1053. https://doi.org/10.1096/fj.08-121962

Lindqvist, A., Sharvill, J., Sharvill, D. E., \& Andersson, S. (2007). Loss-of-function mutation in carotenoid 15,15'-monooxygenase identified in a patient with hypercarotenemia and hypovitaminosis A. The Journal of Nutrition, 137(11), 2346-2350. https://doi.org/10.1093/jn/137.11.2346

Lu, X., Huang, J., Mo, Z., He, J., Wang, L., Yang, X., Tan, A., Chen, S., Chen, J., Gu, C. C., Chen, J., Li, Y., Zhao, L., Li, H., Hao, Y., Li, J., Hixson, J. E., Li, Y., Cheng, M., Liu, X., ... Gu, D. (2016). Genetic Susceptibility to Lipid Levels and Lipid Change Over Time and Risk of Incident Hyperlipidemia in Chinese Populations. Circulation: Genomic and Precision Medicine, 9(1), 3744. https://doi.org/10.1161/CIRCGENETICS.115.001096

Lund, F., Hermansen, M. N., Pedersen, M. F., Hillig, T., Toft-Hansen, H., \& Sölétormos, G. (2015). Mapping of HLA- DQ haplotypes in a group of Danish patients with celiac disease. Scandinavian journal of clinical and laboratory investigation, 75(6), 519-522. https://doi.org/10.3109/00365513.2015.1050688

Matsuo, T., Nakata, Y., Katayama, Y., Iemitsu, M., Maeda, S., Okura, T., Kim, M. K., Ohkubo, H., Hotta, K., \& Tanaka, K. (2009). PPARG genotype accounts for part of individual variation in body weight reduction in response to calorie restriction. Obesity, 17(10), 1924-1931. https://doi.org/10.1038/oby.2009.199 
MdDonough, A. A., \& Youn, J. N. (2017). Potassium Homeostasis: The Knowns, the Unknowns, and the Health Benefits. Physiology (Bethesda), https://doi.org/10.1152/physiol.00022.2016

Merritt, D. C., Jamnik, J., \& El-Sohemy, A. (2018). FTO genotype, dietary protein intake, and body weight in a multiethnic population of young adults: a cross-sectional study. Genes \& nutrition, 13(1), 1-10. https://doi.org/10.1186/s12263-018-0593-7

Mezzavilla, M., Notarangelo, M., Concas, M. P., Catamo, E., Gasparini, P., Grillotti, M. G., \& Robino, A. (2019). Investigation of the link between PROP taste perception and vegetables consumption using FAOSTAT data. International journal of food sciences and nutrition, 70(4), 484-490. https://doi.org/10.1080/09637486.2018.1519527

Mikami, E., Fuku, N., Murakami, H., Tsuchie, H., Takahashi, H., Ohiwa, N., Tanaka, H., Pitsiladis, Y. P., Higuchi, M., Miyachi, M., Kawahara, T., \& Tanaka, M. (2014). ACTN3 R577X genotype is associated with sprinting in elite Japanese athletes. International journal of sports medicine, 35(2), 172-177. https://doi.org/10.1055/s-0033-1347171

Nikitina, M. A., Nikitin, I. A., Semenkina, N. G., Zavalishin, I. V., \& Goncharov, A. V. (2018) Application of the hierarchy analysis method at the foodstuffs quality evaluation. International Journal of Advanced Computer Science and Applications, 9(5), 51-59. https://doi.org/10.14569/IJACSA.2018.090507

Nolden, A. A., McGeary, J. E., \& Hayes, J. E. (2016). Differential bitterness in capsaicin, piperine, and ethanol associates with polymorphisms in multiple bitter taste receptor genes. Physiology \& behavior, 156, 117-127. https://doi.org/10.1016/j.physbeh.2016.01.017

Papadimitriou, I. D., Lucia, A., Pitsiladis, Y. P., Pushkarev, V. P., Dyatlov, D. A., Orekhov, E. F., Artioli, G. G., Guilherme, J. P., Lancha, A. H., Jr, Ginevičienė, V., Cieszczyk, P., MaciejewskaKarlowska, A., Sawczuk, M., Muniesa, C. A., Kouvatsi, A., Massidda, M., Calò, C. M., Garton, F., Houweling, P. J., Wang, G., ... Eynon, N. (2016). ACTN3 R577X and ACE I/D gene variants influence performance in elite sprinters: a multi-cohort study. BMC genomics, 17, 285. https://doi.org/10.1186/s12864-016-2462-3

Patriquin, M. A., Bauer, I. E., Soares, J. C., Graham, D. P., \& Nielsen, D. A. (2015). Addiction pharmacogenetics: a systematic review of the genetic variation of the dopaminergic system. Psychiatric genetics, 25(5), 181-193. https://doi.org/10.1097/YPG.0000000000000095

Pouresmaeili, F., Jamshidi, J., Azargashb, E., \& Samangouee, S. (2013). Association between Vitamin D Receptor Gene BsmI Polymorphism and Bone Mineral Density in A Population of 146 Iranian Women. Cell journal, 15(1), 75-82.

Rodríguez, E., Mateo, I., Infante, J., Llorca, J., Berciano, J., \& Combarros, O. (2006). Cholesteryl ester transfer protein (CETP) polymorphism modifies the Alzheimer's disease risk associated with APOE epsilon4 allele. Journal of neurology, 253(2), 181-185. https://doi.org/10.1007/s00415005-0945-2.

Shramko V. S. (2020). The relationship of fatty acids with indicators of lipid-lipoprotein metabolism disorders in men with coronary atherosclerosis: Sci, Access mode: Dissertation on the topic "The relationship of fatty acids with indicators of lipid-lipoprotein metabolism disorders in men with coronary atherosclerosis", Higher Attestation Commission of the Russian Federation 14.01.05.

Snyder, E. M., Beck, K. C., Dietz, N. M., Joyner, M. J., Turner, S. T., \& Johnson, B. D. (2006). Influence of beta2-adrenergic receptor genotype on airway function during exercise in healthy adults. Chest, 129(3), 762-770. https://doi.org/10.1378/chest.129.3.762

Spracklen, C. N., Chen, P., Kim, Y. J., Wang, X., Cai, H., Li, S., Long, J., Wu, Y., Wang, Y. X., Takeuchi, F., Wu, J. Y., Jung, K. J., Hu, C., Akiyama, K., Zhang, Y., Moon, S., Johnson, T. A., Li, H., Dorajoo, R., He, M., ... Sim, X. (2017). Association analyses of East Asian individuals and trans-ancestry analyses with European individuals reveal new loci associated with cholesterol and triglyceride levels. Human molecular genetics, 26(9), 1770-1784. https://doi.org/10.1093/hmg/ddx062

Tae-Kyung Han (2019). Effects of FABP2 Ala54Thr gene polymorphism on obesity and metabolic syndrome in middle-aged Korean women with abdominal obesity. Central European journal of public health, 27(1), 37-43. https://doi.org/10.21101/cejph.a5077 
Tanwar, V. S., Chand, M. P., Kumar, J., Garg, G., Seth, S., Karthikeyan, G., \& Sengupta, S. (2013). Common variant in FUT2 gene is associated with levels of vitamin B(12) in Indian population. Gene, 515(1), 224-228. https://doi.org/10.1016/j.gene.2012.11.021

Tian, Z., Li, Y. L., Zhao, L., \& Zhang, C. L. (2013). Role of CYP1A2 1F polymorphism in cancer risk: evidence from a meta-analysis of 46 case-control studies. Gene, 524(2), 168-174. https://doi.org/10.1016/j.gene.2013.04.038

Tomczonek-Moruś, J., Wojtasik, A., Zeman, K., Smolarz, B., \& Bąk-Romaniszyn, L. (2019). 13910C>T and $22018 \mathrm{G}>\mathrm{A}$ LCT gene polymorphisms in diagnosing hypolactasia in children. United European gastroenterology journal, 7(2), 210-216. https://doi.org/10.1177/2050640618814136

Weingaertner O., Luetjohann D., \& Vanmierlo T. (2011). Markers of enhanced cholesterol absorption are a strong predictor for cardiovascular diseases in patients without diabetes mellitus. Chemistry and Physics of Lipids, 164, 6, 451-456. https://doi.org/10.1016/j.chemphyslip.2011.03.008

Weiss, R. B., Baker, T. B., Cannon, D. S., von Niederhausern, A., Dunn, D. M., Matsunami, N., Singh, N. A., Baird, L., Coon, H., McMahon, W. M., Piper, M. E., Fiore, M. C., Scholand, M. B., Connett, J. E., Kanner, R. E., Gahring, L. C., Rogers, S. W., Hoidal, J. R., \& Leppert, M. F. (2008). A candidate gene approach identifies the CHRNA5-A3-B4 region as a risk factor for age-dependent nicotine addiction. PLoS genetics, 4(7), e1000125. https://doi.org/10.1371/journal.pgen.1000125

Wiegand, C., Hewitt, N. J., Merk, H. F., \& Reisinger, K. (2014). Dermal xenobiotic metabolism: a comparison between native human skin, four in vitro skin test systems and a liver system. Skin pharmacology and physiology, 27(5), 263-275. https://doi.org/10.1159/000358272

Willer, C. J., Schmidt, E. M., Sengupta, S., Peloso, G. M., Gustafsson, S., Kanoni, S., Ganna, A., Chen, J., Buchkovich, M. L., Mora, S., Beckmann, J. S., Bragg-Gresham, J. L., Chang, H. Y., Demirkan, A., Den Hertog, H. M., Do, R., Donnelly, L. A., Ehret, G. B., Esko, T., Feitosa, M. F., ... Global Lipids Genetics Consortium (2013). Discovery and refinement of loci associated with lipid levels. Nature genetics, 45(11), 1274-1283. https://doi.org/10.1038/ng.2797

Wolffenbuttel, B., Wouters, H., Heiner-Fokkema, M. R., \& van der Klauw, M. M. (2019). The Many Faces of Cobalamin (Vitamin B12) Deficiency. Mayo Clinic proceedings. Innovations, quality \& outcomes, 3(2), 200-214. https://doi.org/10.1016/j.mayocpiqo.2019.03.002.

Wood A. M., Tan S. L., \& Stockley R. A. (2009). Chronic obstructive pulmonary disease: towards pharmacogenetics. Genome medicine, 1(11), 1-10. https://doi.org/10.1186/gm112

Wu, J., Shang, D. P., Yang, S., Fu, D. P., Ling, H. Y., Hou, S. S., \& Lu, J. M. (2016). Association between the vitamin D receptor gene polymorphism and osteoporosis. Biomedical reports, 5(2), 233-236. https://doi.org/10.3892/br.2016.697

Yin, X., Wang, H., Guo, J., Zhang, L., Zhang, Y., Li, L., \& Hou, S. (2018). Association of vitamin D receptor BsmI rs1544410 and ApaI rs7975232 polymorphisms with susceptibility to adolescent idiopathic scoliosis: A systematic review and meta-analysis. Medicine, 97(2), e9627. https://doi.org/10.1097/MD.0000000000009627

Zaridze, D., Maximovitch, D., Lazarev, A., Igitov, V., Boroda, A., Boreham, J., Boyle, P., Peto, R., \& Boffetta, P. (2009). Alcohol poisoning is a main determinant of recent mortality trends in Russia: evidence from a detailed analysis of mortality statistics and autopsies. International journal of epidemiology, 38(1), 143-153. https://doi.org/10.1093/ije/dyn160

Zhang, X., Qi, Q., Zhang, C., Smith, S. R., Hu, F. B., Sacks, F. M., Bray, G. A., \& Qi, L. (2012). FTO genotype and 2-year change in body composition and fat distribution in response to weight-loss diets: the POUNDS LOST Trial. Diabetes, 61(11), 3005-3011. https://doi.org/10.2337/db11-1799 